\title{
Politeness Maxims in the Motive the Forest
}

\author{
Ni Wayan Pramiwidari \\ English Department - Faculty Of Arts - Udayana University \\ [Widariprami@yahoo.com]
}

\begin{abstract}
The title of this undergraduate thesis is "Politeness Maxims in Different Setting of "The Forest movie", which in this writing discussed about the use of Politeness Maxims. The aims of this thesis are to find out about the types and functions of Politeness Maxims and also to analyze the influences of the use of Politeness Maxims in different setting of The Forest movie. The theory used in this undergraduate thesis is The Theory Proposal by Geoffrey Leech. The data in this study were taken from "The Forest movie". The conversations that chosen in this study are implied Politeness Maxims. The data were analyzed based on six maxims stated by leech and then presented descriptively. The result of the analysis shows that there are many expressions of politeness found in "The Forest movie". The characters in "The Forest movie" used politeness maxims more frequently. They talk more politely when they had conversation each other. It was also related to their setting which are famous to their eastern culture. The different setting in this movie also influenced the characters when they had conversations, they had to use Politeness Maxims especially when they talked to other people who were from high class or different social status.
\end{abstract}

Keyword: Word Politeness maxim, function of politeness maxim, western movie.

\begin{abstract}
Abstrak
Judul penelitian ini adalah "Politeness Maxims in the forest movie", dalam tulisan ini membahas tentang penggunaan Politeness Maxims. Tujuan dari tesis ini adalah untuk mengetahui tentang jenis dan fungsi Politeness Maxims dan juga untuk menganalisis pengaruh penggunaan Politeness Maxims dalam setting film The Forest yang berbeda. Teori yang digunakan dalam penelitian ini adalah Teori oleh Geoffrey Leech (1983). Data dalam penelitian ini diambil dari "the forest movie". Percakapan yang dipilih dalam penelitian ini adalah tersiratnya Politeness Maxims. Data dianalisis berdasarkan enam maxsim yang dinyatakan dan kemudian disajikan secara deskriptif. Enam maxim itu adalah the Tact Maxim, the Generosity Maxim, the Approbation Maxim, the Modesty Maxim, the Agreement Maxim, andthe Sympathy Maxim.Hasil analisis menunjukkan bahwa ada banyak ungkapan kesantunan yang ditemukan di "the forest movie". Karakter dalam "the forest movie" menggunakan maxim kesantunan lebih sering. Mereka berbicara lebih sopan saat mereka saling bercakap-cakap. Itu juga terkait dengan setting mereka yang terkenal dengan budaya timur mereka. Pengaturan yang berbeda dalam film ini juga mempengaruhi karakter saat mereka melakukan percakapan, mereka harus menggunakan Politeness Maxims terutama saat mereka berbicara dengan orang lain yang berasal dari kelas tinggi atau status sosial yang berbeda.
\end{abstract}

Kata Kunci : Kata kesantunan, fungsi dari kesantunan, film Barat.

\section{Background of Study}

As living beings, humans need language to interact with other people. Language is a tool used to communicate with one another. There are many ways of communicating with other people around the world; one of them is associated with politeness. It is a thing that must be noticed by humans when they want to interact with one another. 
The use of politeness in speech can be described as the person's private life. Every person has a different level of politeness according to their residence. The use of politeness also deals with their cultures. For example, some people who live in Europe have different cultures from those who live in Asia so the levels of their politeness are different. The use of politeness in an area is influenced by the culture that gives many positive and impacts on community. In this case, the use of politeness and the different setting affects one another. People have to communicate with other people in their daily life. They have conversations to get some information or gain their knowledge about what happens in their environment. When we have conversation we have to be polite so it can create a good communication. Politeness is important in a conversation. Lakoff (1976) stated politeness is best expressed as the practical application of good manners or etiquette.

\section{Problem of Study}

Based on the background above, there are some problems that could be formulated, as follows:

1. What types and functions of politeness maxims are mostly used byin the motive The Forest?

2. What factors affect different usages of politeness maxims in different settings in the movie The Forest?

\section{Aims of Study}

In accordance with the problems ofthe study formulated above, the aims can be divides into:

1. To find out what types and functions of politeness maxims are mostly usedby the characters in the motive The Forest?

2. To analyze the factors affecting different usages of politeness maxims in the different settings in the movie The Forest?

\section{Research Methods}

The section on the method of this study covers three points of discussion, they are as follows:

\subsection{Data Source}

The primary data in this writing were taken from the utterances in the conversations among the characters in the movie "the forest". The movie was directed by Jason Zada and written by Ben Ketai, Nick Antosca, and Sarah Cornwell. It is started by Natalie Dormer and Taylor Kinney. The film was released on January 8, 2016 in the United States by Gramercy picture. The utterance used as the data source is the utterances in the conversations. The movie is the secondary data in this study. The movie script was from the internet and DVD video. This movie was chosen as the data source because there were many conversations associated with politeness expressions, including men and women, women and women, and men, and men.

\subsection{Method and Technique of Collecting Data}

As a movie used as the data source, the first step was about the collection of the data which were obtained by watching and listening to the conversation to understand the story. The movie script was used to understand if there were some conversations that could not be understood. The script movie was downloaded from the internet. Second, the data were noted down to limit which one from the data would be analyzed and picked as the main data. And then, the politeness expressions were found in accordance with their types; they were classified into each maxim; the tact 
maxim, the generosity maxim, the approbation maxim, the modesty maxim, the agreement maxim and sympathy maxim. Lastly, the data were classified again based on six maxims stated by Geoffrey Leech. Its purpose was to focus on the data whether the utterances uttered by the characters in the movie "forest" movie belonged to the tact maxim, the generosity maxim, the modesty maxim, the agreement maxim, or the sympathy maxim. Finally, the data were explained descriptively in order to answer the problems of the study.

\subsection{Method and Technique of Analyzing Data}

The collected data were analyzed descriptively. Analyzing means examining the data in order to understand or discover more about them and descriptively means data are described as clearly as possible. The method used in this study is the qualitative method. It is a method that does not involve measurement or statistics as in the natural science (Boeree, 2005). After collecting the relevant data, the data were analyzed as follows. They are classified whether they are the tact maxim, the generosity maxim, the agreement maxim, and sympathy maxim.

1. The next step was the analysis of the function of each politeness maxim found in the movie "forest" based on the theory proposed by Geoffrey Leech (1983). By using this theory, the use of politeness expression used by the characters can be identified.

2. The last step was the explanation of those politeness maxim meaning.

\section{Result and Discussion}

Regarding to the problem being proposed above, the discussion is focused on six types of politeness maxims proposed by Leech (the Tact Maxim, the Generosity Maxim, and the Approbation
Maxim, the Modesty Maxim, the Agreement Maxim, and the Sympathy Maxim). It focuses on the politeness expressions in the conversation among a number of characters, in the movie "the forest" and also the factors affecting different usages of politeness maxims in different settings in the movie.

\subsection{Japan}

Japan is one of the two settings used in the movie the forest. Japan in this film is regarded as the place where the main character (Sara) has problem with twin sister. In Japan, there are some conversations between characters but not too many conversations use the theory of politeness maxim because some characters use informal language when communicating with new persons. They assume if they meet new persons, they always have the same degree except they are in different ages. There are six conversations using the politeness maxim as follows :

Part 1. Sara; Can I see jess room before I go ?

The Teacher; Yes. Don't worry. I would respect privacy. But, cause you're family. This conversation takes place in Japan between Sara and the Teacher. This utterance applied the Tact Maxim very well. Tact Maxim States 'Minimize the expression of beliefs which imply benefit to other. The teacher as hearer says "can I see jess room before I go? Sara as the first speaker wonders, because she realized that there were clues that could get in Jess's room. In the case, Sara goes to the place jess work; there she meets a student to find information about her twin sister. Politely inquiring to hear the student and assisted by the teacher Sara and the teacher spoke using the politeness maxim well, i.e., can I see jess room before I go? Sara applied negative politeness. This utterance is related to the 
influence of the etiquette of the first speaker which gives benefit to the second speaker. Based on Miller and Smith (2008), they argue if the behavior of someone related to his etiquette and norms lead to being polite or impolite. And she still used can to smoothen her utterance. Sara applies the Tact Maxim well. The reason why Sara is applying the politeness term is the context of situation. The good etiquette of the first speaker makes the second speaker pay attention to her. Although at this moment they don't have close relationship but still pay attention to how to speak more politely to someone who has a big problem.

\section{Part 2.}

Sara; Do you know the forest? Could you take me in, I pay you.

The women; The forest is stay of ures, everybody knows that. Sara is applying the Tact Maxim. The Tact Maxim states that the speaker has to minimize the expression of beliefs which imply cost to hearer, maximize the expression of beliefs which imply benefit to hearer. In the conversation between Sara and the women, Sara wants to know about where the forest is; she asks the women. Sara is doing negative politeness. It is the first time Sara meets the women; their relation is a far one. Sara statement's is not showing the intimacy with the women. The reason why Sara is applying the polite maxim to the women is the context of situation. The relation of Sara and the women is far, therefore, she tries to ask it informal language and polite way with a more indirect sentence do you know about the forest?

\section{Part 3}

Jess : 6 moths ago. I feel bad. We just abandon her. Who else do our own training?

Sara : she is understood. We need to start our lives. I'm about to start mine all over again. I'm sure it would be great, jess. I'm proud of you.

This conversation takes place in America between Sara and Jess. Sara says "she is understood. We need to start our lives. I'm about to start mine all over again. I'm sure it would be great, jess. I'm proud of you", to Jess to show that Sara minimizes dispraise to other and maximize praise to other'. It can be concluded that Sara is amazed to hear the story of jess. Therefore, she gives Jess praise by saying I'm proud of you. Sara gives no dispraise to Jess but very maximizing the praise for Jess. Sara follows the Approbation Maxim well. The positive politeness is applied by Sara. The relation between Sara and Jess is close. She is expressing his intimacy and compliments to Jess after she hears the story of Jess. In this conversation, the good etiquette appears as the factors of expressing the politeness maxim because as a close one, they know how to treat twin sister well; there is problem between them. Based on A. Miller and K. Smith (2008) the etiquette is usually unwritten social "code" by which meanings are interpreted, meaning that although this utterance does not show the etiquette of the speaker directly, it can imply the meaning of the speaker when expressing the utterance. Sara expresses no dispraise in this expression but really maximizes the praise for Jess. In this case, Sara tells her amazed to Sara

Part 4.

Aiden; You search for your sister, it's gripping its human. I mean it's an article. I like your permission to write about it. 
Sara; Right, well. Obviously celebrity in Australia?

This is a conversation between Sara and Aiden at the hotel. Aiden wants to be modest as a reporter. He is saying I like your permission to write about it. He is modestin his conversation and applies the modesty maxim well. The negative politeness is applied by Sara. This is the first meeting of Aiden. She is saying "right, well. Her statement is not minimizing status difference. The reason why Aiden applied the politeness maxims is the social status.

It is simply observed that they are much more direct in expressing agreement, rather than disagreement.

Part 5

Aiden; listen, I have clearance to go with park and guard tomorrow for my articles. He's go around every few days. It's kinda like a suicide watch. He knows the park better than anyone I can ask him that you could come.

Sara; that would be great.

Aiden ; I'm gonna stay here with you.

Michi ; don't be foolish, Aiden.

This expression is intended to show the sympathy to Sara. Sara refuses to believe this, explaining how, being a twin; she can "feel" that jess is still alive. Deep in the woods, the group discovers a yellow tent that Sara recognizes as Jess'. With night fall approaching, Michi suggests they leave anote for Jess and leave. Sara refuses, and Aiden volunteers to stay with her through the night. Michi and Aiden follow the sympathy Maxim very well. The positive politeness is applied by Michi and Aiden inthis conversation. They are used to express intimacy to her. The statement of intimacy is based on the positive politeness.

Part 6

Michi : I still think, you should not go. Sara : Why
Michi : because, you're sad.

This conversation belong to the Generosity Maxim because in this conversation Sara Michi to guard him to the forest; Michi does not want to because he is worried about the sad state of sadness, because the forest that makes them in danger. $\mathrm{He}$ is applying the Generosity maxim well. The positive politeness is applied by Michi in this conversation. It is the first meeting of them. But Michi gives a reason to Sara. $\mathrm{He}$ is applying politeness maxim, because the context of situation. The relation between Sara and Michi is far one.

\section{Conclusion}

Based on the foregoing analysis and discussion, the following point a can be drawn as conclusions. There are six types of politeness maxims found in this movie. They are: Tact Maxim, Generosity Maxim, Approbation Maxim, Modesty Maxim, Agreement Maxim, and Sympathy Maxim. Tact maxim states that minimize the expression of beliefs which imply cost too their and maximize the expression of beliefs which imply benefit to other. Generosity maxim states that minimize the expression of benefit to self and maximize the expression of cost to self. Approbation maxim states that minimize the expression of beliefs which express dispraise of other; maximize the expression of praise of self; maximize the expression of disagreement between self and other; maximize the expression of agreement between self and other. Sympathy maxim states that minimize antipathy between self and other maximize sympathy between self and other. The type of politeness maxims mostly used in this drama is the Agreement Maxim. The reason why the politeness maxim is applied by the characters in this drama is influenced by some factors; they are the context of 
situation (the relation between participant, setting, and topic), age (it means that the younger speakers have to speak politely to the older speaker), gender (women and man have different ways of talking and hence of realizing and interpreting speech acts), kinship (terms indicate blood relationship between the speaker and the hearer), and social status (such as occupation, education and wealth). The most reason for the use of the politeness maxim is the context of the situation (the relationship between the characters).

\section{Bibliography}

Behind.T..S. 2016. The Forest. (CDROM). English.

Brown,P. and Levison, Stephen. 1978. Politeness: Some Universal in language. Cambridge Cambridge University Press.

Elisaberth, Conny. 2014. Politeness Principles in Barrack Obama's Interview. Unimed : Jounal of linguistics.

Hymes, Dell. . 1974. Foundation of Sociolinguistics : An Ethnographic Approach. Philadephia : U of Pennsylvania $\mathrm{P}$.

Holmes, Janet. 1995, Women Men and politeness. London : Longman.

Leech, Geoffrey N.1983. Principles of pragmatics. London : Longman Group Ltd.

Levinson, Stephen C.1983. Pragmatics. United Kingdom : Cambridge University Press

Pratiwi, Kartika Avrianti. 2009. Maxim Application And Context of Situation at Blueline ISP Helpdesk- Operator Field (undergraduate thesis). Denpasar: Udayana University.
Putrid, Desak Nyoman Astri Pradnyani. 2011. Griece's Maxims I Interview between Oprah Winfrey and the Casts of Elipse Movie (Undrgraduate Thesis). Denpasar : Udayana University.

Richards, J.C and Schmidt. (eds). 1983. Language and Communication. London and New York : Longman Group Ltd.

https://en.m.wikipedia.org/wikiThe_Fore $\underline{\text { st_(2016_film) }}$ 